Original article

\section{Alpha fetoprotein: Physiology and pathology during pregnancy and application to antenatal diagnosis}

\author{
Markku Seppälä, Erkki Ruoslahti \\ Dept. II of Obstetrics and Gynecology, University Central Hospital, \\ Dept. of Serology and Bacteriology, University of Helsinki, \\ Helsinki, Finland
}

Received December 13, 1972. Accepted December 27, 1972.
Alpha fetoprotein (AFP) is synthesized by the human fetal liver and yolk sac [8,9]. During the $12^{\text {th }}-14^{\text {th }}$ intrauterine weeks the serum concentration of $A F P$ is at its highest, reaching a few milligrams per $\mathrm{ml}$ [7]. However, the total amount of AFP in the fetus increases until the $22^{\text {nd }}$ week of gestation, remaining constant until about the $32^{\text {nd }}$ week, and thereafter decreasing [7]. In the newborn at term, the serum AFP concentration is $50-150 \mu \mathrm{g}$ per $\mathrm{ml}$ [19]. AFP remains detectable by immunodiffusion or related methods for about 5 weeks after birth [24]. Greatly increased serum AFP levels often reappear in adults with primary hepatocellular cancer [25] or teratocarcinomas [1]. Until recently, the occurrence of AFP in maternal serum had been contested [3].

We purified immunochemically human AFP [14] and developed a radioimmunoassay (RIA) for its determination [15]. It became evident that small amounts (2-16 $\mathrm{ng}$ per $\mathrm{ml}$ ) of AFP are present in normal human serum $[15,16]$. This finding has now been confirmed by other groups [6, 13]. AFP levels in maternal serum increase during pregnancy and the highest AFP concentrations occur during the third trimester. The half life of maternal serum AFP after delivery is about 5 days [19]. In amniotic fluid, the AFP concentrations decrease from the $15^{\text {th }}$ week of gestation, and at term the concentrations are similar to those in maternal serum $[19,21]$.

Recently, we found that the maternal serum AFP concentration often increases in asso-

\section{Curriculum vitae}

MarkKu Seppälä was born in 1936. Doctor of Medicine 1965, University of Helsinki, Thesis: Distribution of serum transferrin groups in Finland and their inheritance. $R e-$ search and teaching assistant at Dept. of Serology and Bacteriology', University of Helsinki 1963-1965. Resident at Dept. of Obstetrics and Gynecology, University Central Hospital, Helsinki 1966-1969. Senior lecturer in Obstetrics and Gynecolog)', 1970. Assistant professor at Dept. II of Obstetrics and Gynecology (Head: Professor PaAvo VARA), University Central Hospital, Helsinki, 1970."



ciation with fetal death [20], and that this increase may occur even before the fetal death [23]. In the present paper we describe results on the AFP concentrations in normal and pathological pregnancies, and evaluate the clinical significance of the serum AFP levels in the antenatal diagnosis of high risk pregnancies.

\section{Materials}

\subsection{Serum samples from pregnant women}

Sera from 204 pregnant women between the $8^{\text {th }}$ and the $42^{\text {nd }}$ week of gestation were studied for the normal range. The following types of high risk pregnancies were investigated: 67 sera from 20 diabetic women, 116 specimens from 74 pregnant women with toxemia or hypertension, and 48 samples from 27 pregnant women with a liver disorder. Intrauterine fetal death occurred in 22 patients. 


\section{$\mathrm{pH}$ Meters for micro-blood tests by the Saling-Turowski method for the exact obstetric diagnosis}

\section{Direct application in the} labour-room.

Digital display

$\mathrm{pH}$ range $\mathrm{pH}$ 0-14

Resolution $0.01 \mathrm{pH}$

$$
\text { Measuring accuracy } \pm 0.005 \mathrm{pH}
$$

Test volume $0.05 \mathrm{ml}$

Time required for

the complete measurement $1 \mathrm{~min}$.

Warranty 3 years
ST 4 for the measurement of the actual $\mathrm{pH}$ value DM 5100

ST 5 with balance device

for the measurement of the actual and metabolic acidity DM 6000

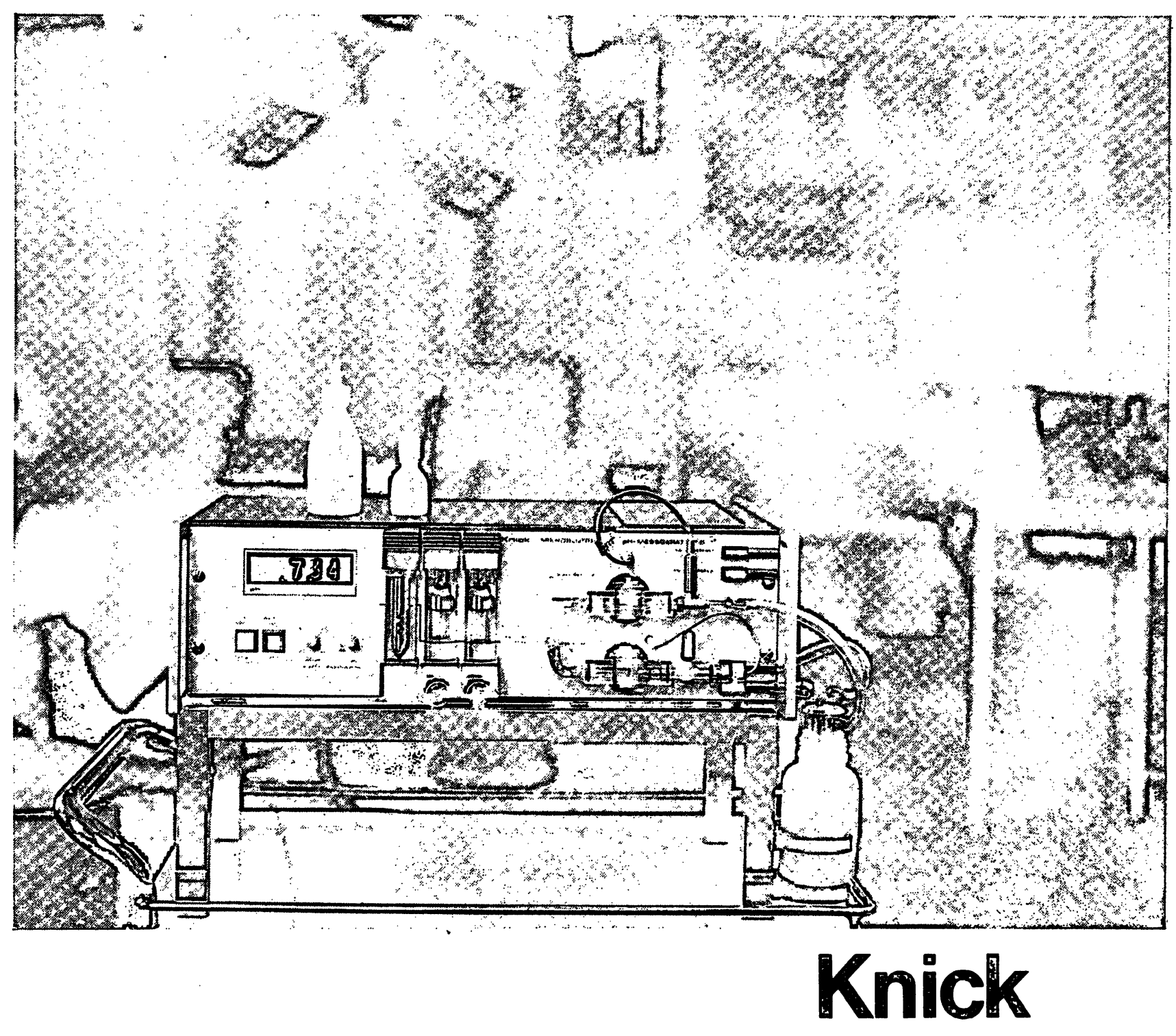

Elektronische Messgeräte

1 Berlin 37, Beuckestraße 22

Tel. (0311) 8001-1, Telex 0184529 


\section{Walter de Gruyter Berlin-New York}

\section{Boschann}

\section{Gynäkologische Zytodiagnostik für Klinik und Praxis}

2nd entirely revised edition of "Praktische Zytologie" With 131 illus., 12 colored tables. 1973. XVI, 161 pp.

Bound DM 54,-; $\$ 20.00$

ISBN 3110039818

\section{Riedel}

\section{Urologische Zytologie}

1973. VIII + 97 pp. with 61 illus. and 8 colored plates.

Bound DM 38,-; $\$ 14.10$

ISBN 3110041189

\section{Gitsch - Palmrich}

\section{Gynäkologisch- operative Anatomie}

Einfache und erweiterte Hysterektomie - Ein Atlas Appendix: Die RadioisotopenRadikaloperation. With an introduction by $\mathrm{H}$. Husslein and I. Amreich. Illustration part by Hans Lang. 1972. XII + 162 pp. With 200 partly varicolored illus. Bound DM 160,-; \$59.25 ISBN 3110034808

\section{Martius}

\section{Geburtshilfe in Stichworten}

With the collaboration of Ulrich Magnus. 1972. 447 pp.

Boards DM 14,80; $\$ 5.50$

ISBN 3110042703

(Sammlung Göschen 7003)

\section{Mosler}

\section{Fetale Herzaktion und Tokographie \\ (Ultrasonographie)}

Atlas für die Geburtshilfe. With the collaboration of Edgar Kitz. 1972. XII +105 pp. 78 illus. Boards DM 56, - ; \$20.75 ISBN 3110042258

\section{Lemtis - Seger \\ Das Rückenlage- Schocksyndrom}

1973. Approx. 96 pp. Boards approx. DM 14,80; \$5.50

ISBN 3110045346

(Sammlung Göschen)

\section{Pschyrembel}

Praktische

\section{Geburtshilfe}

und geburtshilfliche Operationen

14th edition. With the collaboration of Priv. Doz. Dr. Jürg

Bretscher and Prof. Dr. Dietrich Hofmann. 1973. With 612 illus. XXVIII + 899 pp.

Bound DM 68,- ; $\$ 25.25$

ISBN 3110016833

\section{Pschyrembel - Dudenhausen \\ Grundriß der Perinatalmedizin}

1972. IV + 336 pp. With 140 illus. and charts.

Plastic, cover DM 38,-; $\$ 14.10$

ISBN 3110036940

\section{Pschyrembel}

\section{Praktische Gynäkologie}

Für Studierende und Ärzłe

4th revised and enlarged edition. 1968. XXIV + 642 pp. 503 partly varicolored illus.

Bound DM 54, 一; $\$ 20.00$

ISBN 3110008068 


\subsection{Amniotic fluid samples}

Amniotic fluid specimens were collected from 55 normal pregnancies. Fifty-three specimens were collected through an amnioscope by rupturing the fetal membranes, and 2 samples by puncture through the abdominal wall. Eight specimens from 4 high risk pregnancies with severe fetoplacental dysfunction ( 3 diabetic patients and 1 with hydramnion and fetal meningomyelocele) were obtained through abdominal taps. Samples contaminated with red blood were discarded.

\subsection{Homologous antibodies to AFP}

Sera from 10 normal and 10 toxemic pregnancies were collected 4-19 weeks after delivery for the study of AFP antibodies. Serum samples from a further case where twins died in utero were also studied $3-7$ weeks after the delivery (Fig.6).

\section{Methods}

\subsection{Radioimmunoassay of AFP}

AFP was measured by the double antibody radioimmunoassay, as described previously [15]. Serum and amniotic fluid samples were usually assayed at dilutions of 1:25 or higher.

\subsection{AFP in the early human conceptus}

After curettage of a 4-week-old pregnancy, the uterine contents were homogenized in an equal volume $(2.5 \mathrm{ml})$ of saline by teasing them several times through a No. 16 injection needle. After centrifugation, the supernatant and the corresponding maternal serum were examined for AFP in RIA.

\subsection{Search for homologous AFP antibodies}

The test sera were incubated with ${ }^{125}$ I-AFP, after which the precipitation was performed by adding anti-human gamma globulin serum prepared in rabbits. The presence of human antibodies to AFP in the test sera would increase the radioactivity of the precipitate under the test conditions.

\subsection{Assessment of the predictive efficacy of the AFP} test in fetoplacental dysfunction

The normal range was calculated by determining the 95\% tolerance limits for the AFP concentrations in 204 normal pregnancies [10]. AFP concentrations above or below this range were considered abnormal. Severe fetoplacental dysfunction was assumed when two or more of the following signs were present [23]: abnormal fetal heart action (late deceleration or variation greater than 110-170 beats per $\mathrm{min}$ ), fetal acidosis below $\mathrm{pH} 7.25$, meconium in amniotic fluid, retarded intrauterine growth, and intrauterine fetal death. The occurrence of severe fetoplacental dysfunction in the group with normal AFP levels was compared with the group with abnormal AFP concentrations. Clinical decisions were not governed by the AFP concentrations.

\section{Results}

\subsection{AFP in the early human conceptus}

The supernatant of the uterine contents obtained by curettage contained $325 \mathrm{ng}$ of AFP in a volume of $2.5 \mathrm{ml}$, while the corresponding maternal serum AFP concentration was $24 \mathrm{ng}$ per $\mathrm{ml}$.

\subsection{Ninety-five per cent tolerance limits for the AFP concentrations}

The maternal serum AFP concentration in creased from the $8^{\text {th }}$ week of pregnancy. Between 8 and 12 weeks, about one half of the values were above the upper non-pregnant level (16 ng per $\mathrm{ml}$ ). The $95 \%$ tolerance limits for the AFP concentrations as a function of duration of pregnancy are given in Fig. 1. The highest AFP concentrations occurred between 28 and 36 weeks of gestation, where the upper AFP level was about $500 \mathrm{ng}$ per ml.

\subsection{Maternal serum AFP concentrations in diabetic pregnancies}

Of the 67 serum samples from 20 diabetic patients, the highest individual AFP concentrations exceeded the normal range in 4 cases (20\%) (Fig. 2). Fetal distress was present in all of these patients, while distress was found in only 4 of the 16 women (25\%) whose AFP concentrations were within the normal range.

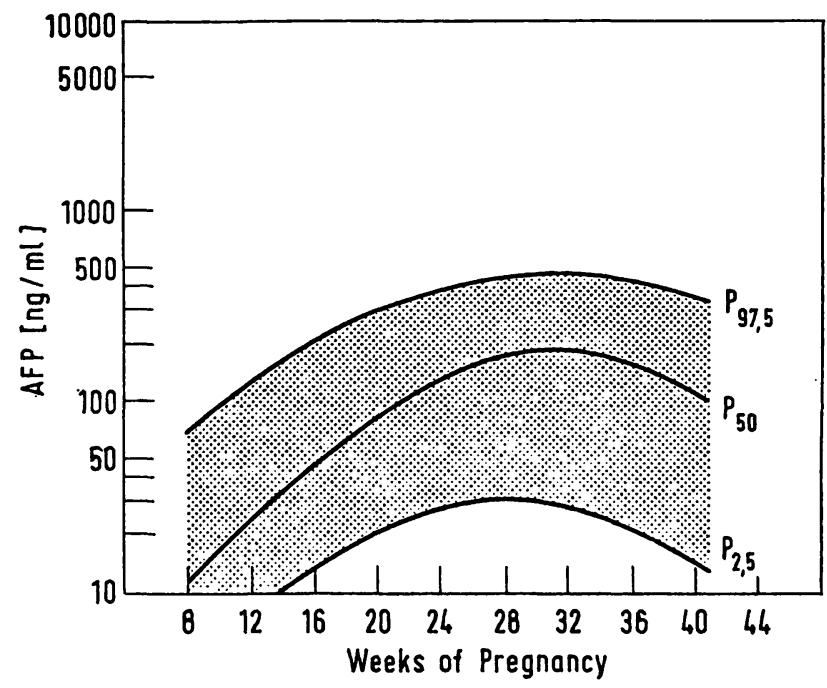

Fig. 1. The $97.5,50$ and 2.5 percentiles (= nonparametric estimation [10]) of the normal AFP concentrations as functions of pregnancy weeks. 


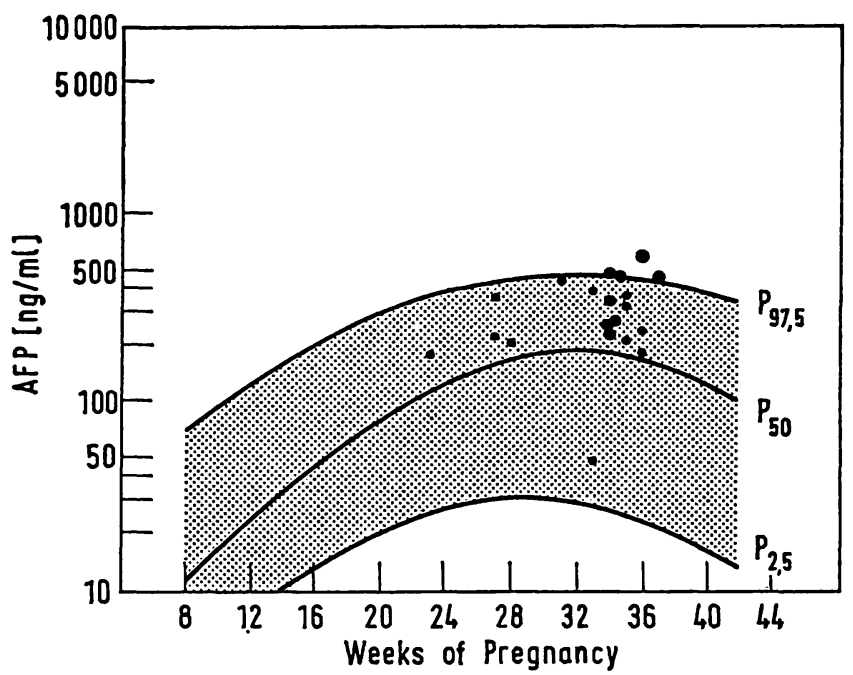

Fig. 2. The highest individual serum AFP concentrations in 20 pregnant women with diabetes mellitus. The larger dots represent severe fetoplacental dysfunction. The normal range is shown by the shaded area.

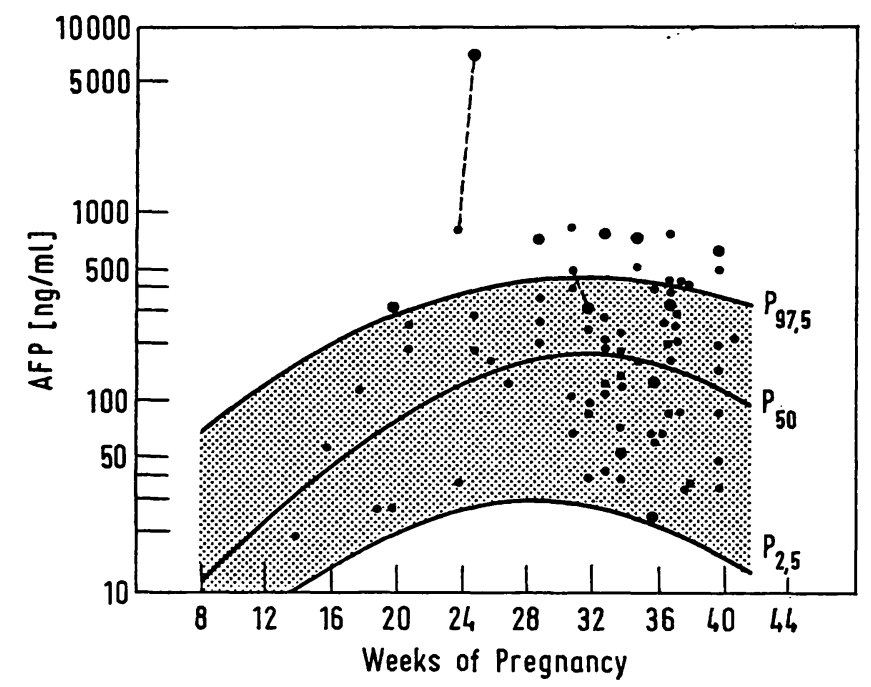

Fig. 3. The highest individual serum AFP concentrations in 74 pregnant women with toxemia or hypertension. The larger dots indicate severe fetoplacental dysfunction. The broken line connecting smaller and larger dots indicates cases where the fetus died in utero: the smaller dots in these cases indicate the AFP concentrations measured at the time when the fetus was alive. The normal range is shown by the shaded area.

\subsection{Maternal serum AFP concentrations in patients with toxemia or hypertension}

Abnormal serum AFP concentrations were present in 14 of the 74 patients (19\%) with toxemia or hypertension (Fig. 3). Severe fetoplacental dysfunction was found in 7 patients with abnormal AFP concentrations (50\%) and in 4 of the 56 women (7\%) with normal AFP levels.

\subsection{Maternal serum AFP concentrations in pregnant women with a liver disorder}

Four of the 27 patients ( $15 \%$ ) with a liver disorder had abnormal serum AFP concentrations (Fig. 4). Severe fetoplacental dysfunction was associated with 2 of these ( $50 \%$ ), and with 3 of the 23 patients with normal AFP levels (13\%).

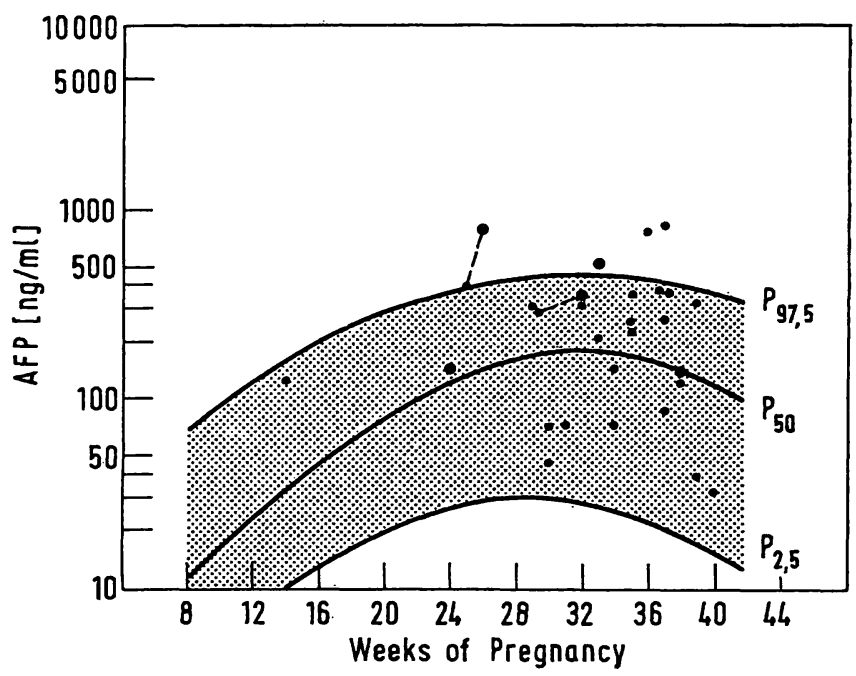

Fig. 4. The highest individual serum AFP concentrations in 27 pregnant women with a liver disorder. The larger dots indicate severe fetoplacental dysfunction. The broken line connecting smaller and larger dots indicates cases where the fetus died in utero: the smaller dots in these cases indicate the AFP concentrations measured at the time when the fetus was alive. The normal range is shown by the shaded area.

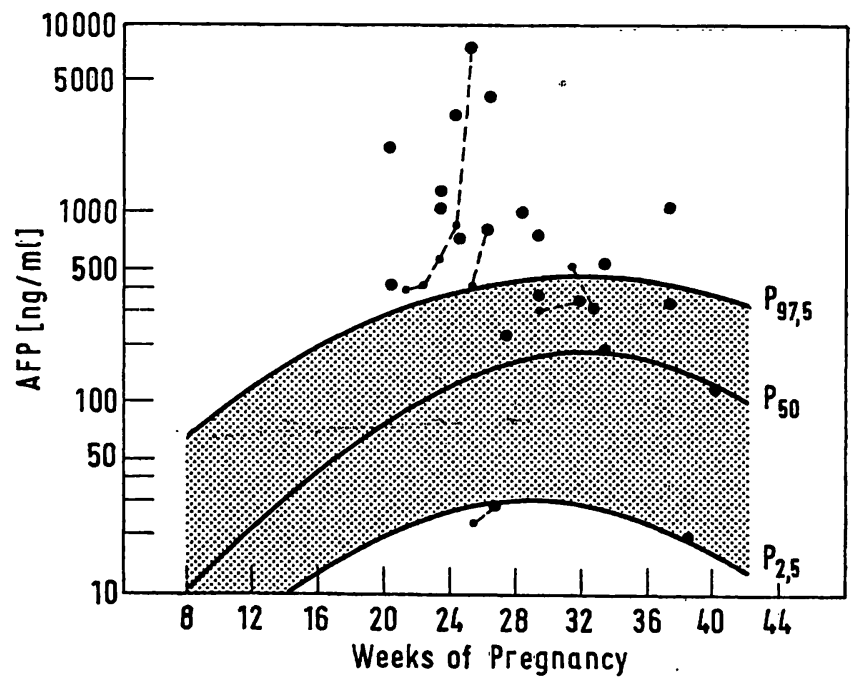

Fig. 5. The highest observed individual serum AFP concentrations in 22 women whose fetus died in utero. The broken line indicates cases where the AFP concentrations were measured while the fetus was still alive: the smaller dots in these cases indicate the AFP concentrations of living fetuses. 


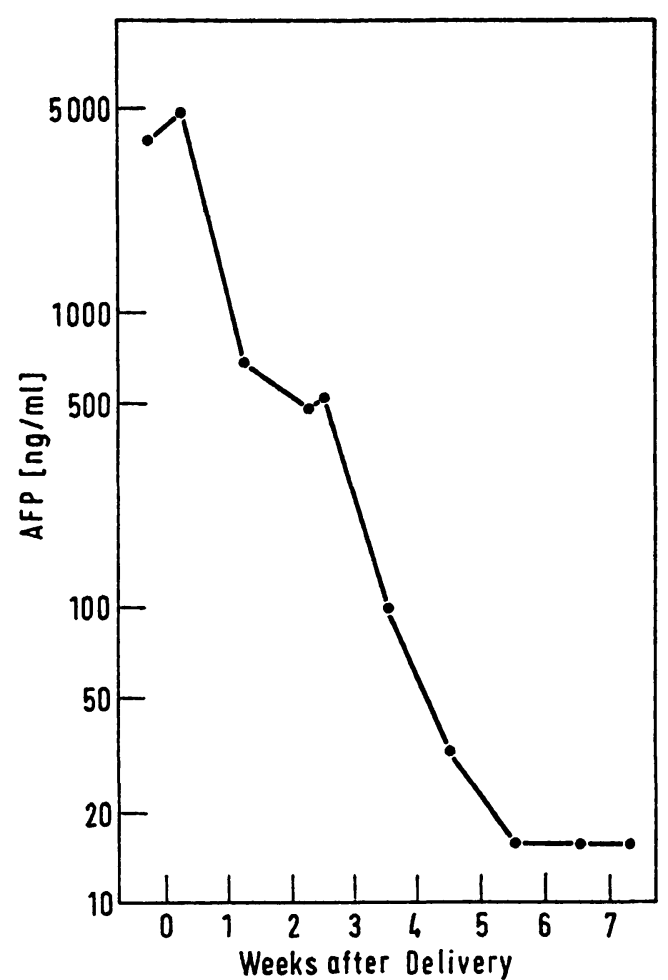

Fig. 6. The AFP concentrations in maternal serum in a case where twins died in utero during the $26^{\text {th }}$ week of gestation. The calculated half life of AFP was 4.2 days.

\subsection{Intrauterine fetal death}

The serum AFP concentrations in the 22 women whose fetus died in utero were abnormal in 15 patients $(68 \%)$ : the concentrations increased in 14 women and were abnormally low in one patient at the time of fetal death (Fig. 5). In a case where twins died in utero during the $26^{\text {th }}$ week of gestation, the AFP concentrations remained above the upper normal pregnancy level for 10 days after delivery (Fig. 6), and the estimated half life of AFP was 4.2 days in this case. Out of the 4 cases where the AFP concentrations were measured before the intrauterine fetal death occurred, increased levels were found in 3 (Fig. 5).

\subsection{Assessment of severe fetoplacental dys- function by the AFP test}

The compiled data from Figs. 2 to 5 indicate that abnormal serum AFP concentrations were associated with severe fetoplacental dysfunction in $59 \%$ of the cases, while normal AFP levels coincided with fetal distress in only $11 \%$ (Tab. I). The difference is highly significant $(\mathrm{p}<0.001)$.
Tab. I. Maternal serum AFP concentrations and fetoplacental function

\begin{tabular}{lcc}
\hline \multirow{2}{*}{ AFP concentration } & \multicolumn{2}{c}{ Fetoplacental function } \\
& Normal & Severe dysfunction \\
\hline Normal $(\mathrm{N}=99)$ & 88 & $11(11 \%)$ \\
Abnormal $(\mathrm{N}=22)$ & 9 & $13(59 \%)$ \\
\hline
\end{tabular}

\subsection{AFP concentrations in normal amniotic fluid}

The AFP concentrations in normal amniotic fluid decreased during gestation. The mean values were $316 \mathrm{ng}$ per $\mathrm{ml}$ at $35-36$ weeks, $164 \mathrm{ng}$ per $\mathrm{ml}$ at $37-38$ weeks, $115 \mathrm{ng}$ per $\mathrm{ml}$ at 39-40 weeks, and $87 \mathrm{ng}$ per $\mathrm{ml}$ at $41-42$ weeks (Fig. 7).

\subsection{AFP concentrations in amniotic fluid of high risk pregnancies}

The AFP concentration in the amniotic fluid of 3 diabetic women increased as the pregnancy advanced during the third trimester. A significant increase in the corresponding maternal serum AFP concentration occurred in one of these

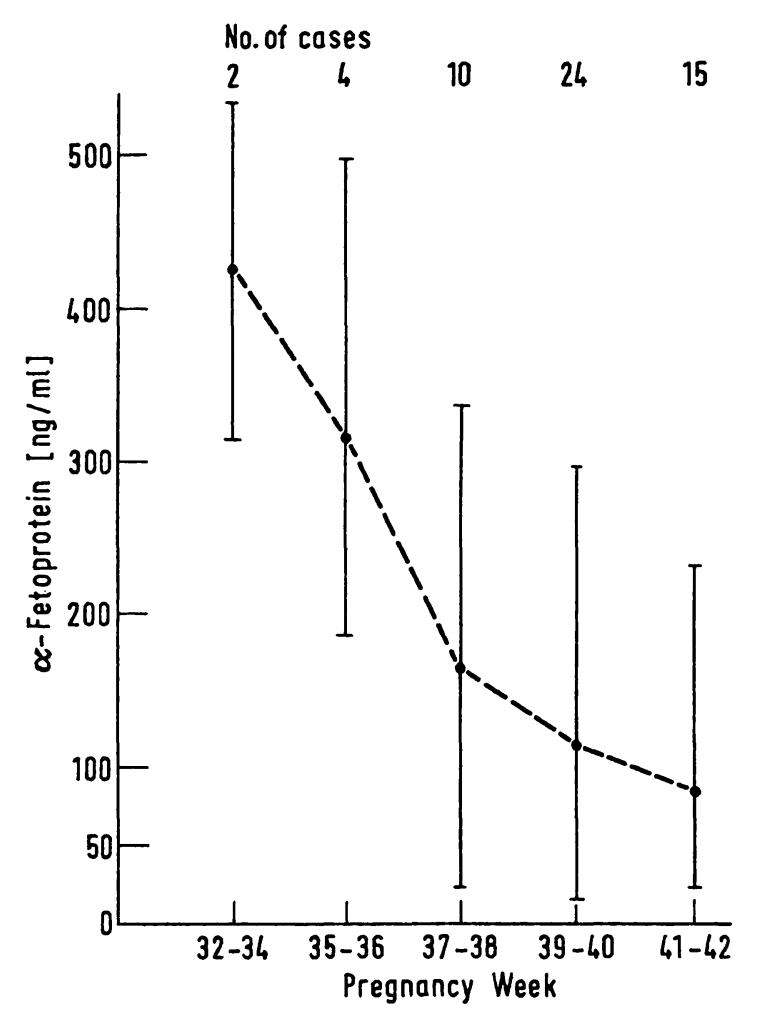

Fig. 7. The mean AFP concentrations and the range in 55 amniotic fluid specimens from normal pregnancies. 

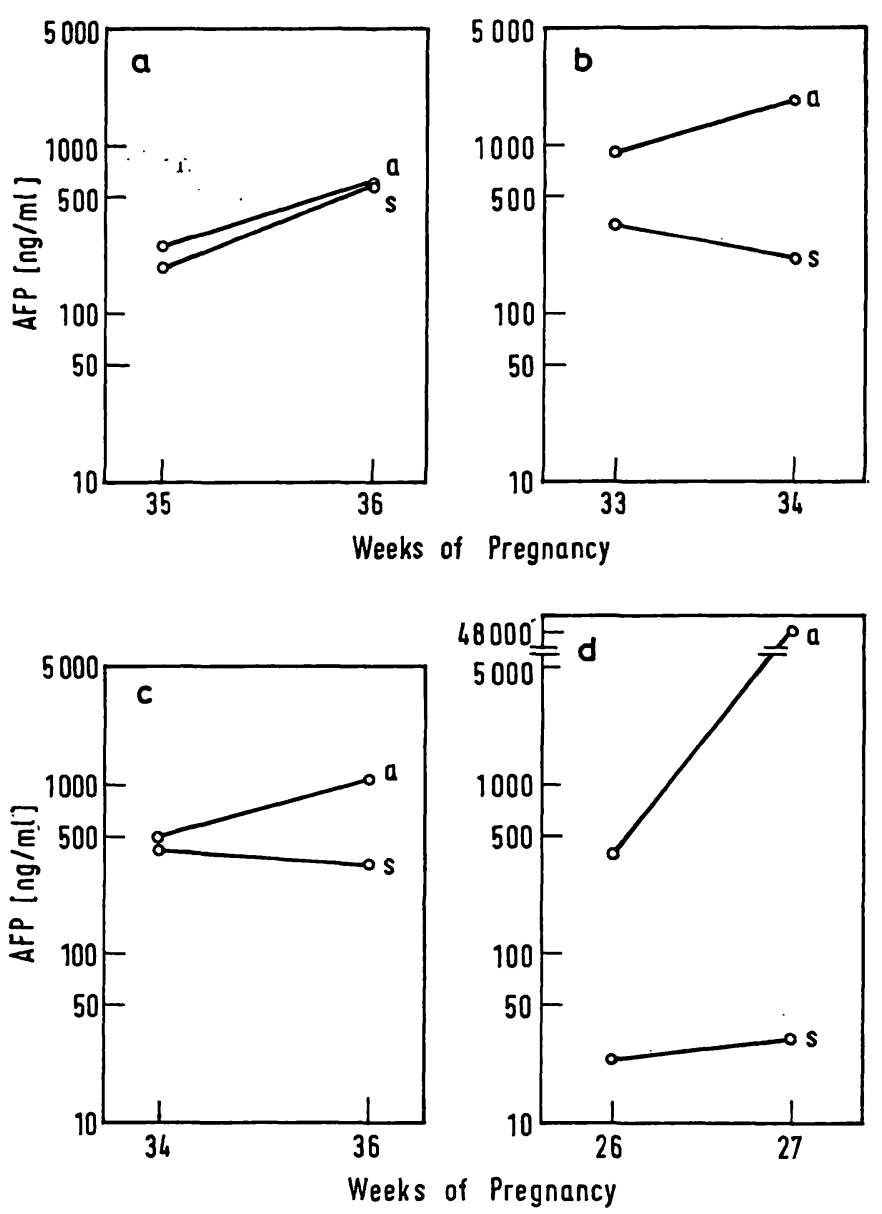

Fig. 8. The AFP concentrations in maternal serum (s) and amniotic fluid (a) in 4 patients with severe fetoplacental dysfunction. Patients $\mathrm{a}, \mathrm{b}$ and $\mathrm{c}$ are diabetic, and $\mathrm{d}$ represents a case where maternal hydramnion was associated with fetal meningomyelocele. Fetus d died in utero.

patients, all of whom were diagnosed as having severe fetoplacental dysfunction (Fig. 8a-c). Polyhydramnion was present in one patient with an amniotic fluid AFP concentration of $400 \mathrm{ng}$ per $\mathrm{ml}$ at the $26^{\text {th }}$ week of gestation. The fetus was alive at that time, but died in utero a week later. The AFP concentration at this time was $48000 \mathrm{ng}$ per $\mathrm{ml}$ (Fig. $8 \mathrm{~d}$ ). The fetus appeared to have meningomyelocele.

\subsection{Homologous AFP antibodies}

Serum samples from 10 normal and 11 pathologic pregnancies did not bind labeled ${ }^{125} \mathrm{I}-\mathrm{AFP}$ at any time (3-19 weeks) after delivery. The result shows that there were no homologous circulating antibodies to AFP that could be demonstrated with the radioimmunoassay employed.

\section{Discussion}

\subsection{The source of AFP}

Alpha fetoprotein was present at a higher concentration in the products of conception than in the maternal serum, which suggests that AFP is being synthesized at an early stage (4 weeks) of pregnancy by the human conceptus.

\subsection{Increased maternal AFP levels}

Abnormally high circulating maternal AFP concentrations were most frequently seen in women whose fetuses died in utero. However, moderate elevations above the normal pregnancy range were also found in women with severe fetoplacental dysfunction. We assume that the increased maternal AFP originates from the fetus in these conditions, although increased maternal AFP concentrations could be anticipated under circumstances in which the maternal liver is affected. This has been observed in some non-neoplastic liver diseases [2, 17]. The increased fetal AFP in the maternal circulation may result from an increased fetal AFP concentration, increased transplacental passage of fetal blood, or transmission of fetal elements from the amniotic fluid to the mother. While all these mechanisms may be operating, there is preliminary evidence indicating that distressed newborn infants have higher AFP concentrations than normal infants of similar gestational ages [12].

\subsection{Low maternal AFP levels}

The significance of low maternal AFP levels is not established. In one patient whose fetus died in utero during the $38^{\text {th }}$ week of gestation, the maternal serum AFP concentration was $20 \mathrm{ng}$ per $\mathrm{ml}$, and rose to $28 \mathrm{ng}$ per $\mathrm{ml}$ after delivery. In the case of a fetal meningomyelocele (Fig. 8d), the maternal serum AFP level was low (30 ng per $\mathrm{ml}$ ) even at a time when the amniotic fluid AFP level had increased to $48000 \mathrm{ng}$ per ml. In another case of severe pre-eclampsia with a distressed fetus; the maternal serum AFP concentration was only $26 \mathrm{ng}$ per $\mathrm{ml}$. It is possible that certain types of diseases lead to increased maternal serum AFP concentrations, while others do not. 


\subsection{Fetal distress and normal maternal AFP levels}

While abnormal maternal serum AFP concentrations were associated with severe fetoplacental dysfunction in $59 \%$ of the cases, fetal distress occurred in $11 \%$ of the women with normal AFP levels. There were 4 women whose fetal distress was correctly indicated by the maternal serum AFP concentration, while the estriol excretion was normal. Our results suggest that the serum AFP level can increase the cumulative efficacy of the biochemical methods used for the monitoring of high risk pregnancies. Even if used alone, high circulating maternal AFP levels are informative from the clinical point of view, since obstetrical decisions in high risk pregnancies rest largely upon the evaluation of risks associated with intervention versus those of waiting, provided that the fetus is considered viable.

\subsection{Amniotic fluid AFP levels in normal pregnancies}

The AFP concentration in amniotic fluid can indicate the gestational age of the fetus in normal pregnancies. In a previous study we showed that the decreasing AFP concentrations in amniotic fluid were related to gestational age rather than to the weight of the infant [21]. A similar decrease occurs in fetal serum during gestation [4]. AFP concentrations smaller than $185 \mathrm{ng}$ per $\mathrm{ml}$ in amniotic fluid indicate that pregnancy has advanced to at least the 37th week. Our values for amniotic fluid AFP concentrations were smaller than those reported by BROCK and SurcLIFFe [5], who found AFP concentrations of as high as $6000 \mathrm{ng}$ per $\mathrm{ml}$ in amniotic fluid samples from the $39^{\text {th }}$ week of gestation. This disagreement can only partly be explained by the different standards used: a pure standard gives smaller concentrations than one less specific. The BEHRINGWERKE standard gives values for AFP twice as high as ours [14].

\subsection{Amniotic fluid AFP levels in pathological pregnancies}

The determination of gestational age by the amniotic fluid AFP level seems to be obscured by changes found in some pathological preg- nancies. In the present series, we examined 4 cases where the AFP concentrations increased at the time when fetal distress developed; normally a decrease is observed. Increasing amniotic fluid AFP concentrations may in certain cases provide a more sensitive marker for fetal distress than maternal serum AFP concentrations. This is indicated by the smaller increase, or even a decrease in the serum AFP levels in diabetic patients with fetoplacental dysfunction, while the amniotic fluid AFP concentrations increased (Fig. $8 \mathrm{a}-\mathrm{c}$ ). We have recently found that the AFP concentrations in amniotic fluid increase in cases of severe maternal Rh-immunization or intrauterine fetal death where no gross fetal malformations are present. It is possible that the high AFP concentrations found in the control samples of BROCK and SUTCLIFFE [5] were related to $\mathrm{Rh}$-immunization and, in the light of the present results, it would be interesting to know whether the remarkably high AFP concentrations found in spina bifida and anencephaly [5] were also related to fetal distress or specifically to the underlying disease. Our case of fetal meningomyelocele was associated with a normal (400 ng per ml) amniotic fluid AFP concentration during the $26^{\text {th }}$ week, but the AFP level increased to $48000 \mathrm{ng}$ per $\mathrm{ml}$ when the fetus died in utero. In addition to fetal distress, leakage of AFP through the meningomyelocele may also have contributed to the marked increase in the amniotic fluid AFP concentration at the time of fetal death.

We found a moderately increased amniotic fluid AFP level and a normal maternal serum AFP concentration in another case where the fetus died suddenly of a cord complication. It seems that the increased circulating maternal AFP concentrations reflect chronic rather than acute fetoplacental dysfunction and that the amniotic fluid AFP levels change more rapidly.

\subsection{The source of amniotic fluid AFP}

Unlike other proteins in amniotic fluid [18, 22], the direct source of the major portion of amniotic fluid AFP seems to be the fetal urine [21], where the AFP concentration is higher than in amniotic fluid. This is true of early but not late pregnancy 
[21]. It would be interesting to know whether the AFP concentrations in newborn urine are higher in distressed than in normal infants.

\subsection{Homologous AFP antibodies}

The AFP concentration of $4200 \mathrm{ng}$ per $\mathrm{ml}$ in maternal serum in a case in which twins died in utero (Fig. 6 ) indicates that more than $10 \mathrm{mg}$ of AFP had passed to the mother. However, no human antibodies to homologous AFP were detected in this case, during pregnancy [19], or in the postpartum sera of several other cases using the radioimmunoassay. Previous contact with high serum AFP conçentrations during the embryonal period results in the recognition of AFP as a "self", and the low AFP concentrations in normal human serum are likely to maintain tolerance to AFP. Recently, it has been shown that rabbits produce antibodies to their homologous AFP when immunized with human AFP [11], which suggests that antibodies to AFP may occur in humans. Radioimmunoassay is sensitive for the detection of antibodies with a relatively high affinity, and our results therefore do not exclude the existence of low affinity antibodies in the cases studied.

\section{Șụmmary}

A. Alpha fetoprotein (AFP) was measured by a highly sensitive radioimmunoassay in tissue homogenate of an early human conceptus, maternal serum and amniotic fluid in normal and high risk pregnancies. Human products of conception contained more AFP than maternal serum at the $4^{\text {th }}$ week of gestation indicating that AFP is synthesized by the human conceptus at this early stage of development.

B. In maternal serum, the AFP concentrations increased with advancing gestation: the highest levels - about $500 \mathrm{ng}$ per $\mathrm{ml}$ - were present during the midthird trimester; these values were based on the AFP levels in 204 normal pregnancies (Fig. 1).

C. Circulating maternal AFP concentrations increased in cases with severe fetoplacental dysfunction. In 67 serum samples from 20 diabetic pregnancies, the AFP concentrations were above the normal range in 4 patients $(20 \%)$. Fetal distress was present in all these cases and in 4 of the 16 women (25\%) whose AFP levels were within the normal range (Fig. 2). In 74 pregnant women with toxemia or hypertension, abnormal serum AFP concentrations were present in 14 (Fig. 3). Severe fetal distress was present in 7 of these $(50 \%)$ and in 4 out of the 60 women (7\%) whose serum AFP concentrations were within the normal range. In patients with a liver disorder, 4 of 27 had abnormal serum AFP concentrations (15\%). Severe fetal distress was present in 2 of these (50\%) and in 3 of the 23 patients with normal AFP levels (13\%) (Fig. 4). In 22 cases of intrauterine fetal death, abnormal maternal serum AFP concentrations occurred in 15 patients (68\%): the AFP levels were increased in 14 women and abnormally low in one (Fig. 5). There were 4 women whose serum AFP concentrations were measured before intrauterine fetal death occurred: the levels were found to be increased in three. Fetal distress was correctly indicated by abnormal maternal serum AFP concentrations in 4 cases where the estriol excretion was normal. In all, abnormal AFP concentrations in maternal serum were associated with severe fetoplacental dysfunction in $59 \%$ of the cases, while normal levels coincided with fetal distress significantly less frequently (11\%) ( $p<0.001$, Tab. I).

D. We assume that the major part of the circulating maternal AFP originates from the fetus, and that the increase above the normal pregnancy range of maternal serum AFP concentration can result from an increased fetal serum AFP level, increased transplacental passage of fetal blood, or transmission of fetal elements from the amniotic fluid to the mother.

E. The maternal serum AFP concentrations remained above the normal pregnancy range for 10 days, and above the upper nonpregnant level for 30 days after delivery of macerated twins (Fig. 6). The estimated half-life of AFP was 4.2 days in this case.

F. In normal amniotic fluid, the AFP concentrations decreased during gestation (Fig. .7). The mean AFP levels ( $\mathrm{ng}$ per $\mathrm{ml}$ ) were: 316 at $35-36$ weeks, 164 at $37-38$ weeks, 115 at $39-40$ weeks, and 87 at $41-42$ weeks. Amniotic fluid AFP concentrations may indicate the gestational age of the fetus in normal pregnancies.

G. In high risk pregnancies, increased AFP concentrations in amniotic fluid were associated with fetal distress. In serial amniotic fluid samples from 3 diabetic pregnancies, the AFP concentrations increased at the time when fetal distress became clinically evident (Fig. 8a-c). In a case of fetal meningomyelocele, the AFP concentration in amniotic fluid was normal in the first specimen, but increased markedly at the time of intrauterine fetal death (Fig. 8d). According to these preliminary results it seems that the AFP concentrations of both maternal serum and amniotic fluid can be useful in the assessment of fetal state in high risk pregnancies.

$H$. A radioimmunologic method was designed to detect naturally occurring human antibodies to AFP. No antibodies could be demonstrated 3-19 weeks after normal or pathologic pregnancies. Previous contact during the embryonal period with high serum AFP con- 
centrations would be expected to result in the recognition of AFP as a "self" during the adult life, and the low AFP concentrations in normal human serum are likely to maintain tolerance to AFP so that even high circulating maternal AFP concentrations are not sufficient to elicit an immune response.

Key-words: Alpha fetoprotein (-antibodies, -physiology, -radioimmunoassay), amniotic fluid, fetus, pregnancy.

\section{Zusammenfassung}

Alpha-Fetoprotein: Physiologie und Pathologie während der Schwangerschaft und die Anwendung auf die vorgeburtliche Zustandsdiagnose

A. Alpha-Fetoprotein (AFP) wurde mittels einer hochempfindlichen Radioimmunmethode im Gewebshomogenat früher menschlicher Embryos und in Serum und Fruchtwasser von Müttern mit normalen und Risikoschwangerschaften bestimmt. Menschliche Embryos enthielten mehr AFP als mütterliches Serum in der vierten Schwangerschaftswoche; dies zeigt an, daß AFP vom menschlichen Embryo in diesem frühen Entwicklungsstadium synthetisiert wird. Im mütterlichen Serum stiegen die AFP-Konzentrationen mit zunehmender Schwangerschaftsdauer an: die höchsten Werte - etwa $500 \mathrm{ng} / \mathrm{ml}$ - traten während der Mitte des 3. Trimenons auf. Dies wurde anahnd von 204 normalen Schwangerschaften bestimmt (Abb. 1).

C. In Fällen mit schwerer feto-plazentarer Dysfunktion waren die mütterlichen AFP-Konzentrationen erhöht. In 67 Seren von 20 diabetischen Schwangeren war die AFP-Konzentration bei 4 Frauen oberhalb des Normbereiches $(20 \%)$. In allen diesen Fällen bestand eine fetale Störung, ebenso wie bei 4 von 16 Patientinnen (25\%) mit normalen AFP-Werten (Abb. 2). Von 74 Schwangeren mit Gestose oder Bluthochdruck waren abnorme AFP-Werte bei 14 vorhanden (Abb. 3). Bei 7 von diesen $(50 \%)$ bestand eine schwere fetale Störung; eine solche lag in 4 der 60 Fälle $(7 \%)$ mit normalen AFPKonzentrationen vor. 4 von 27 Patientinnen (15\%) mit einer Leberstörung hatten abnormale AFP-Werte. Von diesen hatten $2(50 \%)$ eine schwere fetale Störung, während dies bei 3 der 23 Patientinnen (13\%) mit normalen AFP-Werten der Fall war (Abb. 4). Von 22 Fällen mit intrauterinem Fruchttod traten abnorme AFP-Werte bei 15 Patientinnen (68\%) auf: die AFP-Werte waren erhöht bei 14 und abnorm erniedrigt bei einer Patientin (Abb. 5). Bei 4 Frauen wurden die AFP-Konzentrationen vor dem Fruchttod bestimmt: die Werte waten bei drei von ihnen erhöht. Eine fetale Störung wurde durch abnorme mütterliche AFP-Werte richtig angezeigt in 4 Fällen, in welchen die Östriolausscheidung normal war. Im ganzen wurden abnorme AFP-Konzentrationen in mütterlichen Seren in $59 \%$ aller Fälle von schwerer feto-plazentarer Dysfunktion beobachtet, während normale Werte signifikant weniger häufig $(p<0,001)$ bei einer fetalen Störung auftraten $(11 \%$, Tab. I).
D. Wir nehmen an, daß der größte Teil des zirkulierenden mütterlichen AFP vom Feten stammt und daß ein Anstieg über den Bereich der normalen Schwangerschaftswerte entweder von erhöhten fetalen AFP-Werten oder von gesteigertem transplazentarem Ubertritt von Fetalblut oder von der Úbertragung fetaler Elemente vom Fruchtwasser auf die Mutter stammen kann.

E. Mütterliche AFP-Werte blieben oberhalb des notmalen Schwangerschaftsbereiches für 10 Tage und oberhalb der Normwerte für Nichtschwangere für 30 Tage nach der Geburt von mazerierten $Z$ willingen (Abb. 6). Eie Halbwertszeit des AFP wurde in diesem Fall auf 4,2 Tage geschätzt.

F. Im normalen Fruchtwasser fielen die AFP-Werte im Verlauf der Schwangerschaft ab. Die durchschnittlichen AFP-Werte waren: $35-36$ Wochen: $316 \mathrm{ng} / \mathrm{ml} ; 37-38$ Wochen: $164 \mathrm{ng} / \mathrm{ml}$; 39-40 Wochen: $115 \mathrm{ng} / \mathrm{ml} ; 41$ bis 42 Wochen: $87 \mathrm{ng} / \mathrm{ml}$. AFP-Fruchtwasserkonzentrationen könnten das Gestationsalter von Feten bei normalen Schwangerschaften anzeigen.

G. Bei Risikoschwangerschaften waren erhöhte AFPFruchtwasserkonzentrationen mit fetalen Störungen verbunden (Abb. 7). Fortlaufende Bestimmungen bei 3 diabetischen Schwangeren zeigten den Anstieg von AFP zu dem Zeitpunkt an, als eine fetale Störung klinisch festgestellt wurde (Abb. 8a-c). Bei einem Fet mit einer Myelomeningocele war die AFP-Konzentration im Fruchtwasser zunächst normal, stieg jedoch zur Zeit des intrauterinen Fruchttodes beträchtlich an (Abb. 8d). Diese vorläufigen Ergebnisse scheinen auf den Wert der AFPBestimmung im mütterlichen Serum und im Fruchtwasser für die Zustandsdiagnose von Feten bei Risikoschwangerschaften hinzuweisen.

H. Es wurde eine Radioimmunmethode zur Bestimmung natürlich vorkommender menschlicher Antikörper gegen AFP entwickelt. Es konnten keine Antikörper 3 bis 19 Wochen nach einer normalen oder pathologischen Schwangerschaft entdeckt werden. Ein vorausgegangener Kontakt mit hohen AFP-Konzentrationen während der Embryonalperiode könnte zur Erkennung des AFP als "self" beim Erwachsenen führen. Die niedrigen AFP-Werte im normalen menschlichen Serum bewirken wahrscheinlich eine Toleranz gegen AFP, so daß selbst hohe mütterliche AFP-Werte nicht zur Auslösung einer Immunreaktion führen.

Schlüsselwörter: Alpha-Fetoprotein (-Antikörper, -Physiologie, -Radioimmunbestimmung), Fetus, Fruchtwasser, (Risiko-)Schwangerschaft. 


\section{Résumé}

Alpha foeto-protéine: physiologie et pathologie lors de la grossesse, et application aux diagnostics prénataux

A. L'Alpha foeto-protéine (A. F. P) a été dosée par une méthode radio-immunologique, méthode particulièrement sensible, dans un homogéinat de tissus provenant d'un embryon humain très jeune, dans le sérum maternel et le liquide ammiotique de grossesses normales et de grossesses à haut risque.

Le foetus humain contenait plus d'A. F. P. que le sérum maternel à la 4ème semaine de la grossesse, indiquant que l'A. F. P. est synthétisée par le foetus à ce stade très précoce du développement.

B. Dans le sérum maternel, le taux d'A. F. P. augmente avec le terme: les taux les plus hauts, de l'ordre de 500 n. g. par millilitre, ont été trouvés au milieu du troisième trimestre (étude portant sur le taux d'A. F. P. de 204 grossesses normales; fig. 1).

'C. Le taux circulant d'A. F. P. maternel est augmenté dans les cas qui comportent un dysfonctionnement foeto-placentaire sévère. Dans une série de 67 échantillons de sérum provenant de 20 femmes enceintes diabétiques, le taux d'A. F. P. était supérieur à la normale chez 4 patientes $(20 \%)$. La souffrance foetale existait dans tous ces cas mais aussi chez 4 des 16 femmes (25\%) dont le taux d'A. F. P. était sensiblement normal (fig. 2).

Chez 74 femmes enceintes, présentant une toxémie gravidique ou. une hypertension, des concentrations anormales d'A. F. P. existaient dans 14 cas (fig. 3). Une souffrance foetale sévère existait 7 fois sur ces 14 cas (50\%) mais aussi chez 4 des 60 femmes (7\%) dont le taux d'A. F.P. était sensiblement normal.

Parmi les 27 patientes présentant une affection hépatique, 4 avaient un taux anormal d'A. F. P. (15\%), une souffrance foetale sévère existait chez deux d'entre elles (50\%) et chez 3 des 23 patientes ayant des taux normaux d'A. F. P. (13\%) (fig. 4).

Dans 22 cas de mort foetale in utéro, des taux maternels anormaux d'A. F. P. furent trouvés chez 15 patientes (68\%): élevés dans 14 cas, anormalement bas dans un cas (fig. 5). Dans 4 autres cas, on a pu mesurer le taux maternel d'A. F. P. avant la mort foetale: il était élevé dans trois cas.

La souffrance foetale a été correctement détectée par un chiffre anormal d'A. F. P. dans 4 cas où l'oestriol urinaire était normal.

En bref un taux anormal d'A. F. P. dans le sérum maternel était associé à un dysfonctionnement foeto-placentaire sévère dans $59 \%$ des cas, tandis que des taux normaux
$: 1$

coincidaient avec une souffrance foetale nette avec une fréquence moindre ( $11 \%$ ) ( $\mathrm{p}<0.001$, tab. I).

D. Nous pensons que la plus grande partie de 1'A. F. P. circulante chez la mère provient du foetus, et que l'augmentation du taux sérique maternel d' A. F. P. audessus du taux gravidique normal peut provenir soit d'un taux sérique foetal augmenté, soit d'un passage sanguin foeto-maternel augmenté, ou bien d'un passage d'éléments foetaux du liquide amniotique vers la mère. E. A la suite de l'accouchement de deux jumeaux macérés, le taux sérique maternel d'A. F. P. s'est maintenu audessus du taux gravidique normal pendant 10 jours, et au-dessus du taux maximum que l'on peut rencontrer en dehors de la grossesse pendant 30 jours (fig. 6). La demivie de 1'A. F. P. estimée dans ce cas est de 4,2 jours.

F. Dans le liquide ammiotique normal, la concentration d'A. F. P. décroit pendant la gestation. Les taux moyens d'A. F. P. (nanogramme par millilitre) étaient de: 316 à $35-36$ semaines, 164 à $37-38$ semaines, 115 à 39-40 semaines, 87 à $41-42$ semaines.

La concentration amniotique d'A. F. P. peut être susceptible d'indiquer l'âge gestationnel d'un foetus lors d'une grossesse normale.

G. Dans les grossesses à haut risque des taux d'A. F. P. augmentés dans le liquide amniotique étaient associés à une souffrance foetale (fig. 7). Dans des séries d'échantillons de liquide amniotique provenant de 3 femmes enceintes diabétiques, la concentration amniotique d'A. F. P. a augmenté au moment où la souffrance foetale devenait cliniquement évidente (fig. $8 \mathrm{a}-\mathrm{c}$ ).

Dans un cas de myéloméningocèle, la concentration amniotique d'A. F. P. était normale dans le premier échantillon, mais a augmenté très notablement au moment de la mort foetale in utéro (fig. 8d).

Selon ces premiers résultats; il semble que le taux d'A. F. P. aussi bien dans le sérum maternel que dans le liquide amniotique puisse être un élément utile d'appréciation de l'état foetal dans les grossesses à haut risque.

H. Une méthode radio-immunologique éțait apte à détecter des anticorps naturels anti A. F. P. Il n'en a pas été trouvé 3 à 19 semaines après des grossesses normales ou pathologiques.

Un contact préalable pendant la période embryonnaire avec de hautes concentrations sériques d'A. F. P. est susceptible d'expliquer la reconnaissance ultérieure de l'A. F. P. comme «non étrangère» à l'âge adulte; de plus, l'existence d'un très faible taux sérique d'A. F. P. chez l'adulte normal est susceptible de maintenir une tolérance vis à vis de l'A. F. P. de telle manière que même les taux élevés chez la femme enceinte ne sont plus susceptibles d'induire une réponse immunitaire.

Mots-clés: Alpha foeto protéine (-anticorps, -dosage radioimmunologique, -physiologie), grossesse (-à haut risque), foetus, liquide amniotique, souffrance foetale.

\section{Acknowledgements}

We thank Prof. P. Vara, M. D., and Prof. S. Trmonen, M. D., for the clinical material, Miss S. SorkKeli, Miss H. Kallio, Miss S. Rrstimäki and Miss L. Salminen for technical assistance, and Mr. T. Partanen, M. Sc., for statistical advice. This study was supported by grants from the Finnish Medical Research Council and the Sigrid Juselius Foundation. 


\section{Bibliography}

[1] Abelev, G. I., I. V. Assercritova, N. A. Kraevsky, S. D. Perova, N. I. Perevodchikova: Embryonal serum $\alpha$-globulin in cancer patients: diagnostic value. Int. J. Cancer 2 (1967) 551

[2] Abelev, G. I., V. S. Tsvetkov, T. I. Biryulina, D. A. Elgort, A. M. Olovnikov, A. I. Gusev, A. K. Yazova, S. D. Perova, I. V. Rubtsov, S. V. Shaborina, B. A. Kantorovich, V. M. Tur, A. I. Khazanov, D. M. Levina: Assessment of the use of highly sensitive methods of determining alpha-fetoprotein for the diagnosis of hepatocellular cancer and teratoblastoma. Biull. eksp. Biol. Med. 4 (1971) 75

[3] Alpert, E., J. Zuckerman: Absence of $\alpha_{1}$-fetoprotein antigen or antibody in maternal sera. Lancet (1970) II, 465

[4] Bergstrand, C. G., B. W. Karlsson, T. Lindberg, H. EkELUND: $\alpha$-foetoprotein, albumin and total protein in serum from preterm and term infants and small for gestational age infarts. Acta Paediat. Scand. 61 (1972) 128

[5] BRock, D. J. H., R. G. SuTClIfFE: Alpha-fetoprotein in the antenatal diagnosis of anencephaly and spina bifida. Lancet (1972) II, 197

[6] Elgort, D. A., G. I. Abelev, G. T. O'Conor: Dependence of the specificity of the serologic test for primary liver cancer in different areas of the world on sensitivity of the method used for detecting alphafetoprotein. Int. J. Cancer 10 (1972) 331

[7] Gitlin, D., M. Boesman: Serum $\alpha$-fetoprotein, albumin and $\gamma$-globulin in the human conceptus. J. Clin. Invest. 45 (1966) 1826

[8] Gitlin, D., M. Boesman: Sites of serum $\alpha$-fetoprotein synthesis in the human and in the rat. J. Clin. Invest. 46 (1967) 1010

[9] Gitlin, D., A. Perricelli: Synthesis of serum albumin, prealbumin, $\alpha$-foetoprotein, $\alpha_{1}$-antitrypsin and transferrin by the human yolk sac. Nature (Lond.) 228 (1970) 995

[10] Herrera, L.: The precision of percentiles in establishing normal limits in medicine. J. Lab. Clin. Med. 52 (1958) 34

[11] Nishi, S., H. Watabe, H. Hirar: Production of antibody to homologous $\alpha$-fetoprotein in rabbits, rats and horses by immunization with human $\alpha$-fetoprotein. J. Immunol. 109 (1972) 957
[12] Nørgaard-Pedersen, B.: Personal communication 1972

[13] Purves, L. R., M. Purves: Serum alpha-feto-protein. VI. The radio-immunoassay evidence for the presence of AFP in the serum of normal people and during pregnancy. South Afr. Med. J. 46 (1972) 1290

[14] Ruoslahti, E., M. Seppälä: Studies of carcinofetal proteins: Physical and chemical properties of human $\alpha$-fetoprotein. Int. J. Cancer 7 (1971) 218

[15] Ruoslahtr, E., M. Seppälä: Studies of carcino-fetal proteins. III. Development of a radioimmunoassay for $\alpha$-fetoprotein. Demonstration of $\alpha$-fetoprotein in serum of healthy human adults. Int. J. Cancer 8 (1971) 374

[16] Ruoslahti, E., M. SeppäLÄ: $\alpha$-foetoprotein in normal human serum. Nature (Lond.) 235 (1972) 161

[17] Ruoslahtr, E., M. Seppälä: Normal and increased alpha-fetoprotein in neoplastic and non-neoplastic liver disease. Lancet (1972) II, 278

[18] Ruoslahtr, E., T. Tallberg, M. Seppälä: Origin of proteins in amniotic fluid. Nature (Lond.) 212 (1966) 841

[19] Seppälä, M., E. Ruoslahtr: Radioimmunoassay of maternal serum alpha fetoprotein during pregnancy and delivery. Amer. J. Obstet. Gynec. 112 (1972) 208

[20] SEPPÄLÄ, M., E. Ruoslaht: $\alpha$-fetoprotein in normal and pregancy sera. Lancet (1972) I, 375

[21] Seppälä, M., E. Ruoslahtr: Alpha fetoprotein in amniotic fluid: An index of gestational age. Amer. J. Obstet. Gynec. 114 (1972) 595

[22] Seppälä, M., E. Ruoslahtr: Proteins and nonprotein nitrogen compounds in amniotic fluid and their clinical significance. Scand. J. clin. Lab. Invest. 29 (1972) suppl. 126

[23] Seppälä, M., E. Ruoslahti: Alpha fetoprotein in maternal serum: a new marker for detection of fetal distress and intrauterine death. Amer. J. Obstet. Gynec. 115 (1973) 48

[24] Seppärä, M., T. Tallberg, C. Ehnholm: Studies on embryo-specific proteins. Physiological characteristics of embryo-specific alpha-globulin. Ann. Med. exp. Fenn. 45 (1967) 16

[25] Tatarinov, Y. S.: Content of embryo-specific alpha-globulin in the blood serum of human foetus, newborn and adult man in primary cancer of liver. Vop. med. Khim. 11 (1965) 20

M. Seppälä, M. D. University Central Hospital Dept. II of Obstetrics \& Gynecology SF-00290 Helsinki 29

Finland 